\title{
МОНГОЛ ОРНЫ ЧУЛУУННУУРСНИЙ ГАЛАВЫН УРГАМЛЫН СУДАЛГААНААС
}

Л. Уранбилэг

ШУА-ийн Палеонтологийн төвийн ЭШАA, Ph.D.

\section{ОРШИЛ}

Монгол орны чулууннүүрсний (карбон) галавийн мөхсөн ургамлын судалгаа хэд хэдэн үе шаттайгаар явагдсан байна. УГ судалгааг 19-р зууны сүүлч, 20-р зууны эхэн үеэс эхэлсэн гэж үздэг бөгөөд анхны олдворууд нь цөөн тооны үлдэгдлүүд байв. 1970-аад оны эхэн үеэс хоёр дахь үеийн судалгааг Гурван-Хараат уул, Цагаансуварга (Өмнөговь), Мэргэн уул (Ховд), Орхон голын сав газар зэрэг голлох олдворт газруудын хэмжээнд явуулсан байна (Дуранте М.В.,1976). Сүүлийн жилүүдэд Улаан толгой, Шарга морьт, Хүрэн толгой (Говь-алтай),Бор толгод (Өмнөговь), Цагаан-суварга (Дорноговь) нутагт эртний ургамлын үе шатны судалгаа явагдаж тодорхой үр дүнд хүрлээ. Манай орны нүүрс агуулсан хурдас чулуулгууд нь чулууннүүрс, пермь, юр, цэрдийн цаг үетэй салшгүй холбоотой байдаг. Чулууннүүрсний үеийн ургамлын судалгааг явуулах нь Монгол орны нүүрсний орд, илрэлүүдийн судалгаа, хурдас хуримтлалын цаг хугацаа,талбайн тархалтын зүй тогтлыг илрүүлэх, эх газрын хурдас чулуулгийн насыг тогтооход чухал ач холбогдолтой юм. Энэхүу өгүүлэлд Өмнөд-Монголын бүсэд хамаарагдах Улаан толгой, Шарга морьт, Хүрэн толгой, Бор толгод, Цагаан-суваргын олдворт газрын чулууннүүрсний үеийн ургамлын судалгааны зарим шинэлэг үр дүнг тусгахыг зорив (зураг 1).

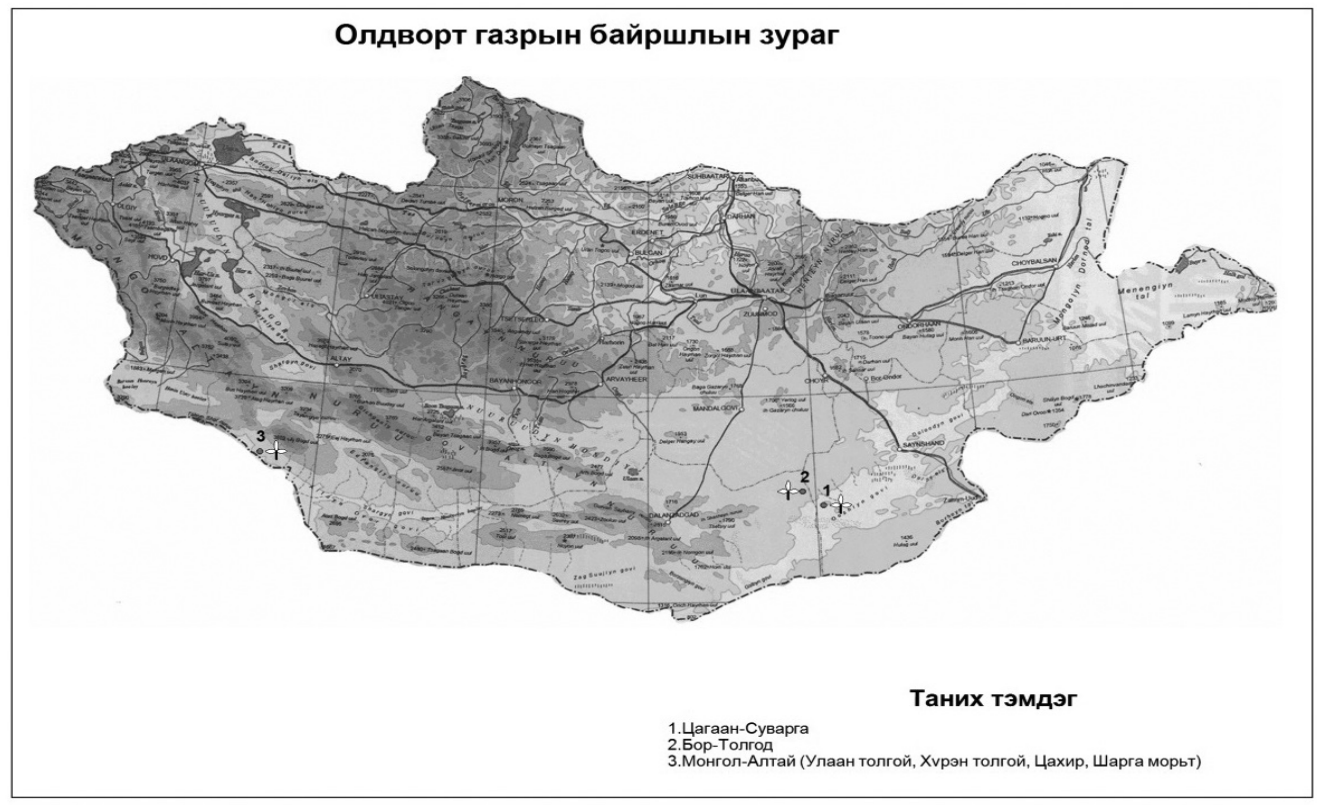

Зураг 1. Олдворт газрын байрильн зураг.1-Цагаан суварга, 2-Бор толгод, 3-Монгол-Алтай (Улаан толгой, Хүрэн толгой, Шарга морьт). 


\section{СУДАЛГАА, АРГА ЗҮЙ.}

Монгол Алтайн бүсийн томоохон нутаг дэвсгэрийн хэмжээнд 1990-ээд оны дунд үеэс 1:200000-ын, 1:50000-ын масштабын геологийн зураглал, ашигт малтмалын эрэл хайгуулын ажил нилээд өргөн хүрээтэй явагдсан байна. Үүний дараa 2004-2006 онуудад Монгео ХХК-ийн 1:50000-ын масштабын “Янгирт-улаан50 ” зураглалын ажил хийгдсэн юм. Эдгээр ажлын үр дүнд тус бүс нутгийн геологийн тогтоц, давхарга зүй, хурдас чулуулгийн тархалтын зүй тогтол, зонхилох ашигт малтмалуудын ерөнхий тойм тогтоогдсоны үндсэн дээр алт, зэсийн болон нүүрсний хэд хэдэн илрэл, олон арван эрдэсжсэн цэгүүдийг шинээр олж илрүүлсэн байна.

2000-аад оны дунд үе хүртэл Улаан толгой, Шарга морьт, Хүрэн толгой зэрэг газраас эртний ургамлын олдвор илрээгүй байв. Харин Монгео ХХК-ийн явуулсан ажлын үр дүнд тус компанийн геологчид эртний ургамлын олдворыг анх олж илрүүлсэн нь эдгээр нүүрсний шинэ илрэлүүдтэй холбоотой юм (зураг 1, 2).

Геологич Б. Бямбаа нарын үзсэнээр L-46-117-Г, L-46-117-Б хавтгайнуудад хамаарагдах өмнөд хилийн дагуух бүсэд дээр өгүүлсэн нүүрсний дөрвөн шинэ илрэл нь Хятад улсын нутаг дэвсгэрт одоо ашиглагдаж байгаа нүүрсний ордуудын үргэлжлэл байж болох хэтийн төлөвтэй гэж дүгнэснийг энд дурьдах нь зүйтэй.

Нөгөө талаас, эдгээр нүүрстэй хурдсын нас нь тодорхой бус байсан явдал агуулагч хурдаст хадгалагдан үлдсэн ургамлын нарийвчилсан судалгаа хийх шаардлагыг бий болгов.

Монгол-Алтайн нүүрсний эдгээр илрэлүүдийн газар зүйн байрлал ба геологийн тогтцыг товч тодорхойлоход, Улаан толгой, ХУрэн толгойн олдворт газрууд нь L-46-117-Г хавтгайд хамаарагдах бөгөөд. чулуулгийн гарш нь намхан жижиг толгодын орой, хотос газруудаар илэрнэ. Хурдас нь сайн мөлгөржсөн конгломерат, гравелит, алевролит, алаг болон цайварсаарал элсжин, улаавтар-ягаан өнгийн элсэрхэг шавар, нүүрс зэргээс бүрдэнэ. Хурдсын бусад хурдастай харьцах харьцаа нь тодорхой ажиглагддаг онцлогтой.

Шарга морьтын олдворт газар нь L-46117-Б талбайн зүүн-урд хэсгийн багахан талбайд оршиж ерөнхийдөө, улаавтар, ягаавтар-саарал элсжин, алевролит, гравелит, жижиг хайргат конгломератаас тогтоно. Чулуулгийн гарш харьцангуй муу тул давхаргазүйн бүрэн зүсэлт хийгдэх боломжгүй болохыг зураглалын ажлын явцад геологичид ажигласан байдаг.

Зохиогч эдгээр шинэ олдворт газруудаас илрүүлсэн эртний ургамлын судалгаа хийсний үр дүнд үе иштний хүрээний Paracalamites sp., Phyllotheca (?) sp., ойм төстний бүлгийн Angarapteridium neuburgae Durante (зураг 3), A. verbitskajae Durante (зураг 4), Angarapteridium sp. зэрэг дээд чулууннүүрсний цаг үеийн зонхилох ургамлыг (Дуранте М.В.,1976; Флора фанерозоя, 2009) тогтоосон нь агуулагч хурдсын насны найдвартай үндэслэл болсон юм (Уранбилэг Л., Бямба Б., Батнасан Ш., 2007).

Урьдах судалгаагаар эдгээр нүүрстэй хурдсыг чулуулгийн харьцуулсан судалгаанд үндэслэн дээд цэрдийн цаг үед хамааруулж байв.

Харин энэ судалгаагаар анх дээд цэрдийн цаг үед хамааруулж байсныг шинэчлэн өөрчилж нүүрстэй хурдсыг дээд чулууннүүрсний эхэн үед хуримтлагдсан болохыг тогтоосон нь уг судалгааны гол бөгөөд шинэлэг үр дүн юм. 


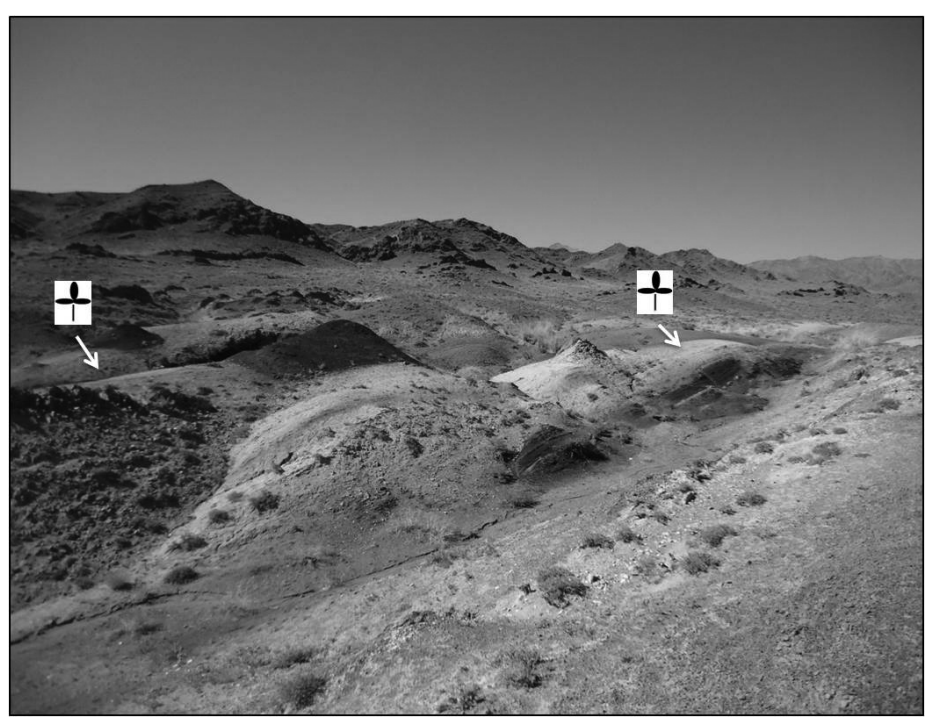

Зураг 2. Монгол-Алтайн бүсэд тогтоогдсон эртний ургамал агуулагч нүүрстэй хурдас чулуулгийн гадаргууд илэрсэн байдал.

Монгол-Алтайн бүсээс илэрсэн дээд чулууннүүрсний үеийн мөхсөн ургамлын олдворыг зураг 2-д үзүүлэв.

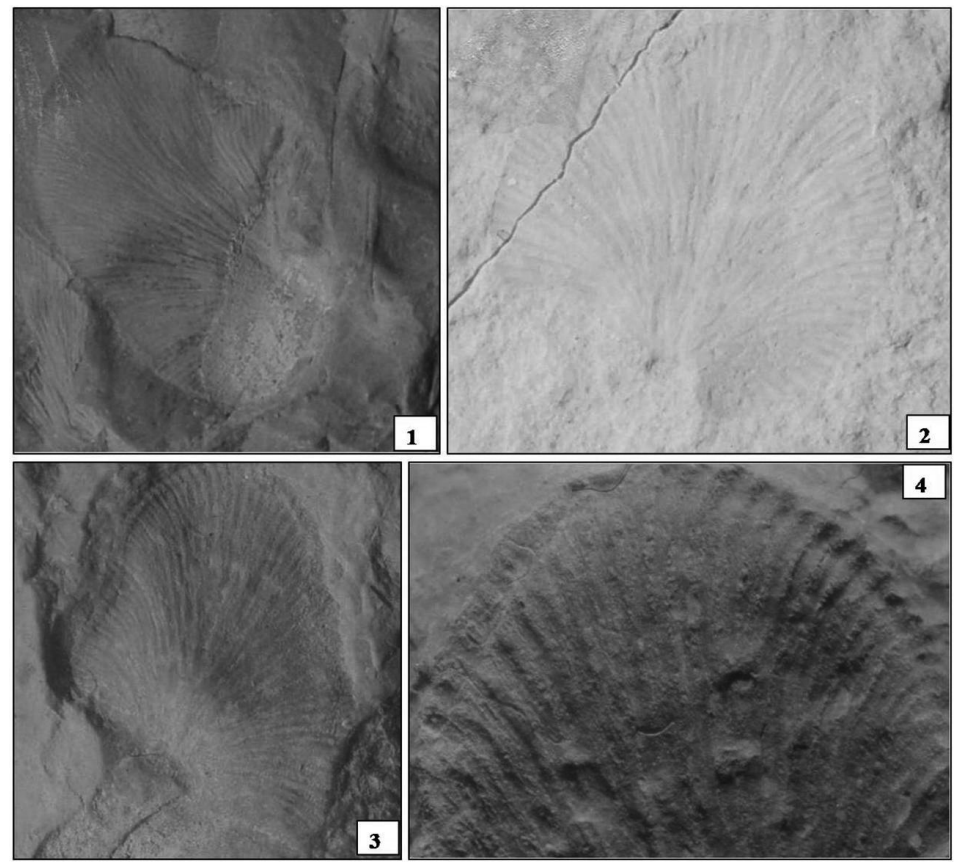

Зураг 3. Ойм төстний хүрээний ургамльн үлдэгдлүүд чулуулагт хадгалагдсан нь.

1-2: Angaropteridium neuburgae Durante, 1-(x 2,5), Говь-Алтай аймаг, Алтай сум, ХУрэн толгой, 2-(x2), Улаан толгой, 3-4: Angaropteridium verbitskajae Durante, 3-(x 2), Улаан толгой, 4-(x 2,5), Шаргал морьт, дээд чулууннүүрсний эхэн үе, 320-315 орчим сая жилийн өмнөх.

$$
-17-
$$


Бор толгод нэртэй олдворт газар нь Өмнөговь аймгийн Манлай сумын төвөөс зүүн-урагш 60 гаруй км-т оршино (зураг $1,4,5)$. Бидний үзсэнээр энэ нутгийн геологийн тогтоцнь нилээд сонирхолтой, энд хэд хэдэн давхаргазүйн нэгжид хамаарагдах хурдас тархалттай бөгөөд тэдгээрийн өөр хоорондын харьцааг ажиглах боломжтой. В.И. Гольденберг нарын (1978ф) явуулсан 1:200000-ын масштабын геологийн зураглал, ашигт малтмалын эрэл хайгуулын ажлын талбайн нэгээхэн хэсэг нь Бор толгодын орчим нутаг байв. Гэвч, урьдах судалгаагаар эндээс палеонтологийн ямар нэгэн олдвор илрээгүй байна.

Бидний (Л.Уранбилэг, Ч.Төмөрчөдөр, Т.Энхбат) 2013 оны хээрийн судалгааны явцад (N4343' 46' 55,3" /E107²9' 23,7"ээс N4346' 49,7" /E107²9' 27,9”) ияохиот формач $\left(C_{2} c t\right)$ гэж зураглагдсан туфоген хурдас нь ургамал бүхий үеүдийг агуулсан болох нь тогтоогдож, энэ нь тухайн хурдсын давхаргазүйн судалгаанд чухал шинэ баримт болсон юм. Урьд нь энэхүү хурдсын насыг зөвхөн чулуулгийн давхаргазүйн шинжээр нь тогтоосон байдаг бөгөөд ийм хурдас Гурванхараат, Цохиотын хийд, Манхан уул, Хөх толгой, Өлзийтийн хяр, Элгэн уул, Ханбогдын массивын дүүрэгт зураглагдсан байдаг (Стратиграфи, 2012). Уг хурдсыг Цохиотын хийдийн нэрээр ижил нэртэй газарт М.В. Дуранте (1976) анх зузаалагт ялгаж ургамлын үлдэгдлийн судалгаагаар насыг тогтоосон бол В.И. Гольденберг нар (1978ф) судалж баталгаажуулан дээд чулууннүүрсний үеийн формац (свит) болгон ангилсан байна (Бямба Ж. нар, 1996).

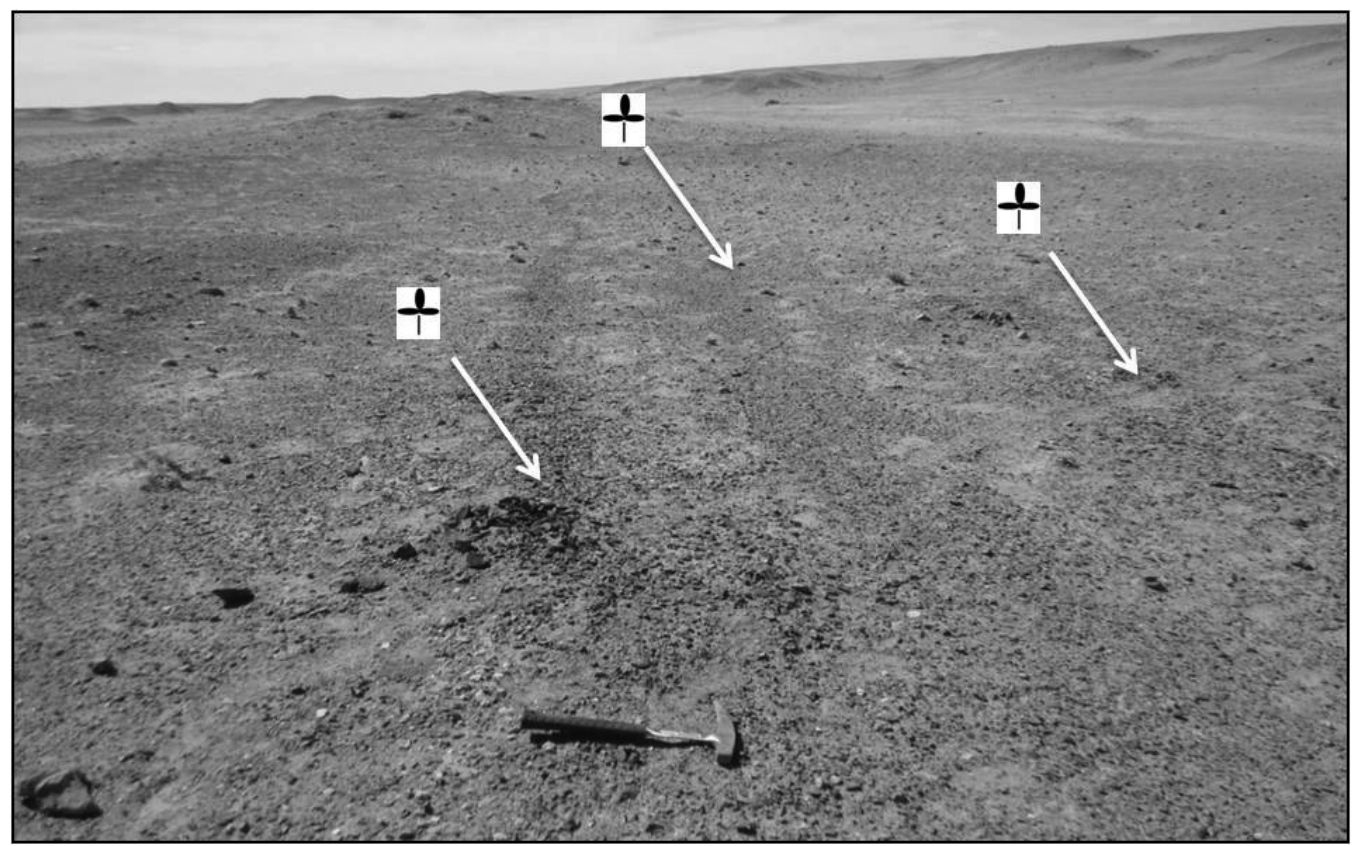

Зураг 4. Бор толгод нэртэй олдворт газрын эртний ургамал агуулагч чулуулгийн үеүд.

Энэ формацын чулуулаг мөргөцөг формацын терриген хурдас дээр нийцлэгээр байрлах боловч дээд хил нь тогтоогдоогүй байна. Чулуулаг нь ногоовтор-саарал, хар-саарал өнгөтэй андезит, андезитбазальт, риодацит, риолит, тэдгээрийн туф, туф-элсжин, туф-алевролит, туффит, конгломератаас тогтоно. Ургамалтай үеүдээс (зураг 4) дээд чулууннүүрсний цаг үеийг баттай тодорхойлох Angaropteridium cardiopteroides (Schm.)Zal., Angaropteridium sp. зэрэг ангароптеридиумын ургамльн 
нэгдлийн (Дуранте, 1976) баялаг олдвор олдсон нь хурдсын насыг баталгаажуулах үндэслэл болов. Бор толгод орчмоос илэрсэн эртний ургамлын олдворыг зураг 5-д үзүүлэв.
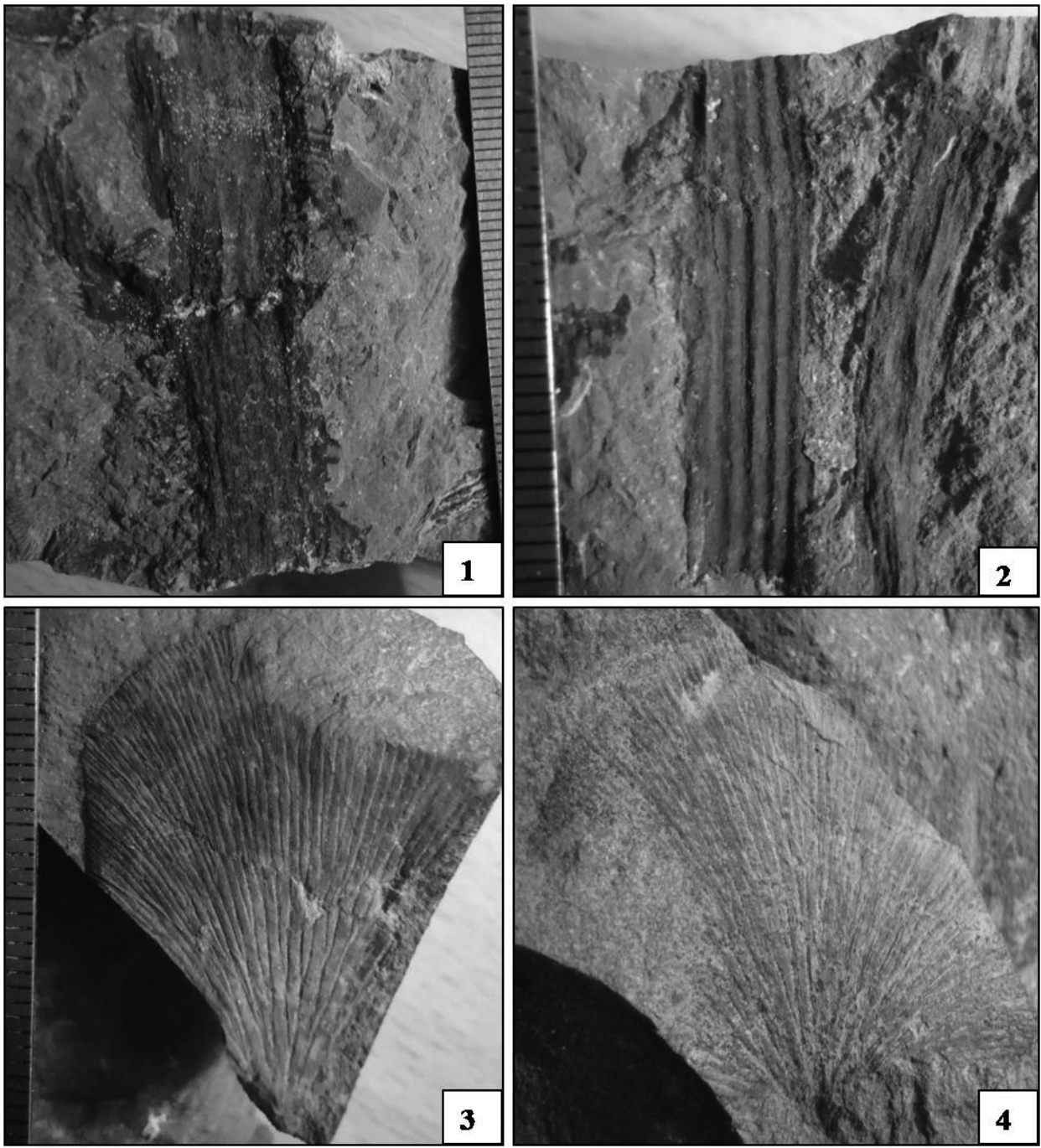

3ураг 5. 1, 2: уе иитэн-Paracalamites sp. (x1,2), 3, 4: ойм төстөн Angaropteridium cardiopteroides (Schm.) Zal., 1- (xl,5), 2- (x1,5), Өмнөговь аймаг, Манлай сум, Бор-толгод, дээд чулууннүүрсний галавын эхэн үе, 320-315 орчим сая жилийн өмнөх.

Цагаан-суваргын олдворт газар нь Дорноговь аймгийн Мандах сумын төвөөс урагш 70 орчим км-т оршино. Энд тархсан тунамал ба тунамал-галт уулын чулуулгаас тогтох хурдсыг С.Н. Алексейчик, А.Я. Стефаненко,В.С.Волхонин,П.Ф.Чебаненко, Н.Ф. Вологдин, Ю.А. Борзаковский, О.Д.
Суетенко, Б.И. Васильев, М.В. нар судалж зүсэлтийг өгсөх дарааллаар байрлах далайн хэмхдэст хурдас, доод туфогентунамал, галт уулын ба дээд туфогентунамал хурдсын зузаалгуудад ангилсан байна. Зүсэлтийн доод туфоген-тунамал хурдсаас илрүүлсэн ургамлын үлдэгдлийг 
M.В. Дуранте судлаад Angaropteridium cardiopteriodes (Schm.) Zal.,Abacanidium sp. зэрэг зүйл ургамал байгааг тогтоосон (Стратиграфи, 2012).

Уг олдворт газраас (Д. Оролмаагийн цуглуулга, 2013) илрүүлсэн ургамлын үлдэгдлийг зохиогч судлаад М.В.
Дурантегийн (1976) Монгол орны карбоны эх газрын хурдсын хувьд боловсруулсан ангароптеридиумын ургамлын нэгдэлд хамаарагдах Angarapteridium mongolicum Durante (Дуранте, 1976), нутгийн хэв шинжит ургамал болохыг тогтоов.

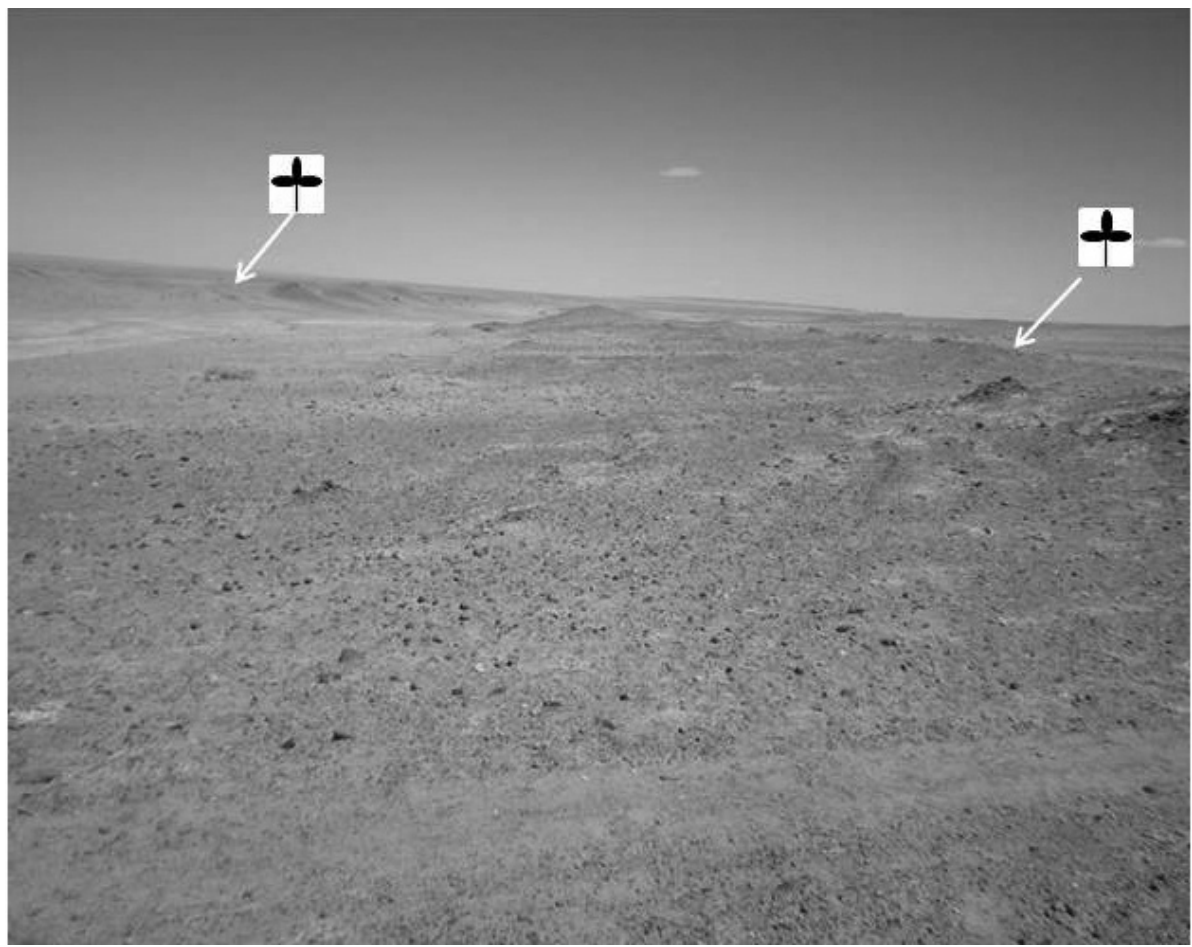

Зураг 6. Цагаан суваргын орчим газарт тархсан хожуу карбоны ургамал агуулагч хурдас.

Цагаан-суваргын олдворт газраас илэрсэн Angarapteridium mongolicum Durante зүйл ургамлын чулуулагт хадгалагдсан байдлыг зураг 7-д харуулав. 


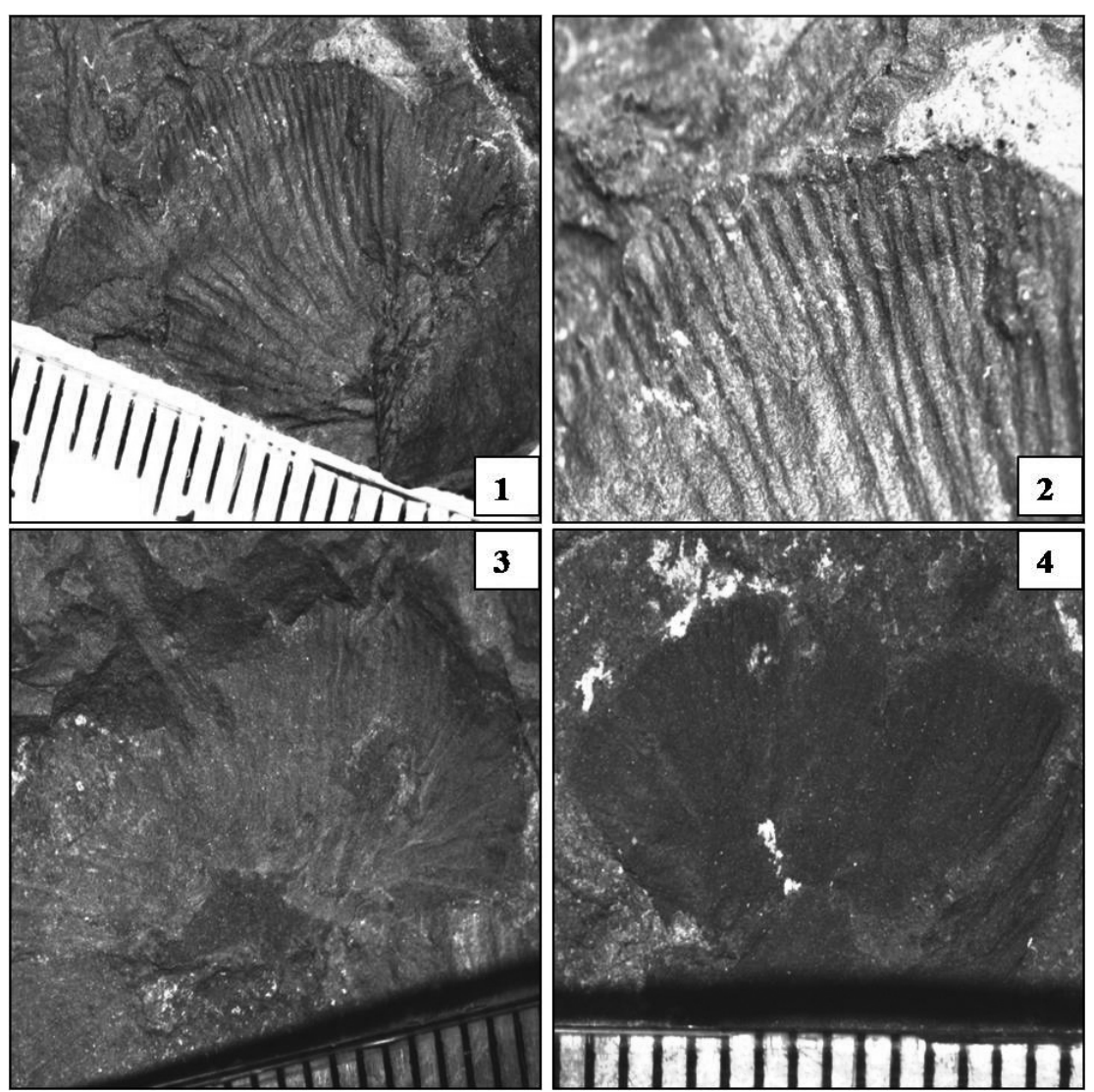

Зураг 7. 1-4: ойм төстний навч чулуулагт хадгалагдсан нь, Angarapteridium mongolicum Durante (x2), Өмнөговь аймаг, Манлай сум, Бортолгод, дээд чулууннүҮрсний галавын эхэн үе, 320-315 орчим сая жилийн өмнөх.

Энэ ургамлын бүтцийн өвөрмөц шинж чанар сайн хадгалагдсан байгааг тэмдэглэх хэрэгтэй. Үүнд үндэслэн, ургамал агуулагч хурдсыг дээд чулууннүүрсний

\section{ДҮГНЭЛТ}

Монгол-Алтайнбүсэдилэрсэннүүрстэй хурдас чулуулгууд нь дээд чулууннүүрсний цаг үед хуримтлагдсан болохыг тогтоосон (Уранбилэг Л., 2006).

Бор толгодын олдворт газраас ургамлын үлдэгдлийг анх илрүүлж хурдсын насыг баталгаажуулсан.

Цагаан-суваргын орчим газраас нутгийн хэв шинжит ургамал илрүүлсэн нь урьдах судалгааны үр дүнг баяжуулав. эхэн үед хамааруулж эртний ургамлын ангилалзүйн бүтэц бүрэлдэхүүнийг шинэ материалаар баяжуулав.

\section{Судалгааны нутгудад бүтэц} бүрэлдэхүүний хувьд нэг төрлийн (монодоминант) ургамал (Angaropteridium) зонхилж байгааг тогтоов.

Эдгээр олдворууд тухайн цаг үеийн голлох нүүрс үүсгэгчид мөн (Мейен С.В., $1987)$ тул Монгол орны тодорхой нутгийн нүүрс хуримтлалын үйл явцтай холбон ойлгох нь зүйтэй юм. 


\section{ТАЛАРХАЛ}

Энэхүу өгүүллийг бичих явцад мэргэжлийн үнэт зөвлөлгөө өгсөн ШУАийн Палеонтологийн төвийн эрдэмтэн нарийн бичгийн дарга Ё. Ханд, хээрийн судалгааны ажилд хамтран ажиллаж анхдагч материал бүрдүүлэлтэнд тусалсан доктор Д.Оролмаа, геологич Ч.Төмөрчөдөр, Т.Энхбат, техникийн арга аргачилалын ажилд оролцож ажилласан залуу судлаач Г.Цолмон, Б.Ганбат нарт талархал илэрхийлж байна.

\section{Ашигласан бүтээлийн жагсаалт}

1. Бямба Ж., Минжин Ч., Уранбилэг Л. нар, 1996, Монголын стратиграфийн толь. Х. 144.

2. Гольденберг В.И. и др., 1978ф. Геологическая съёмка и поиски полезных ископаемых масштаба 1:200000 в пределах Южногобийского, Среднегобийского и Восточногобийского аймаков.

3. Дуранте М.В. 1976, Палеоботаническое обоснование стратиграфии карбона и перми Монголии //Тр., ССМГЭ, вып. 19, С. 8-25, 80-87, 102-115, М., Наука.

4. Мейен С.В., 1987, Основы палеоботаники, С. 323-327.

5. Стратиграфи, 2012 //Монголын геологи ба ашигт малтмал, Х. 280-330УУя, “Эрдэнэт үйлдвэр“ ХХК.

6. Уранбилэг Л., 2006, Монгол орны эртний ургамал /МУШУТИС-ийн Геологи-Газрын тосны сургуулийн бүтээл, Геологи сэтгүүл, Улаанбаатар, №4, Х. 83-91.

7. Уранбилэг Л., Батнасан Ш., Бямба Б., 2007, Карбоны нүүрсний шинэ илрэлүүдийн насны үндэслэлд (Монгол Алтай) //Монголын Геосудлаач, Улаанбаатар, №30, Х. 15-17.

8. “Флора фанерозоя Монголии“", 2009,// "Палеонтология Монголии“, Тр., ССМПЭ, С. 91, 252, М., ГЕОC. 